\title{
Performance of fresh market tomato (Solanum lycopersicum L.) lines as influenced by pruning
}

\author{
Nelda R. Gonzaga ${ }^{\text {* }}$, Apolinario B. Gonzaga Jr', Sarah Lyn A. Pepito' \\ and Gordon Rogers ${ }^{2}$
}

\begin{abstract}
Tomato production in the Philippines is dominated by conventional farmers who do not practice pruning. Currently, rampant occurrence of diseases almost wiped out the industry and availability of resistant seeds became a problem however several studies reported that pruning lessened diseases and enhanced yield. The study aimed to evaluate the effect of pruning on the performance of different fresh market tomato genotypes. The experiment was laid out in factorial design using Randomized Complete Block Design with pruning as Factor $\mathrm{A}$ and tomato genotypes as Factor B with Harabas (Harabas Rescuer 746) as control. Pruning obtained thicker stem and $18 \%$ higher fruit set, reduced Tomato Yellow Leaf Curl Virus and increased tomato yield by producing a higher number of marketable fruits. AVTO 1173 produced the heaviest and largest fruits with the least TYLCV. Pruning is a beneficial practice that farmers could adopt, along with AVTO 1173 as a substitute for the Harabas, check variety. Additional trials of AVTO 1173 should be conducted in different locations to further verify its adaptability and performance in other situations.
\end{abstract}

Keywords: Tomato Yellow Leaf Curl Virus, AVRDC, AVTO 1173, disease resistance

\section{INTRODUCTION}

In tomatoes, pruning involves the removal of lateral branches, retaining only the main stem. This is done to maximize the efficiency of photosynthesis as well as minimize the risk of diseases. Maintaining pruned, single-stemmed tomato plants maximizes light interception by the leaves, resulting in larger fruit that are steadily produced (Chen \& Lal 1999).

Pruning in tomatoes has been reported to increase yield and quality and reduced susceptibility to pests and diseases (Kanyomeka \& Shivute 2005). Ferrandino (2010) claimed that pruning improves plant health because leaves of

${ }^{1}$ College of Agriculture University of Science and Technology of Southern Philippines - Claveria MOSCAT Compound, Poblacion, Claveria 9004, Misamis Oriental, Philippines

${ }^{2}$ Applied Horticultural Research, Eveleigh, NSW Australia

* Corresponding Author. Address: University of Science and Technology of Southern Philippines Claveria, MOSCAT Compound, Poblacion, Claveria 9004, Misamis Oriental, Philippines; Email: npr.gonzaga@gmail.com DOI: 10.32945/atr39sb8.2017 
Performance of fresh market tomato

pruned plant dries off faster after irrigation or rainfall, reducing spread of bacterial and fungal pathogens. Muhammad and Singh (2007) also indicated that pruning results in erect upright plants that are less infected with leaf spot and fruit rot as their leaves stay drier and free from pathogen-laden soil.

A number of TYLCV resistant fresh market tomato seed lines developed by the World Vegetable Center (AVRDC) are currently available. However, the seed lines are expensive and not readily available to small land-holder farmers in the Philippines thus local farmers have no choice but to use other readily available varieties that may not be resistant to the virus. To reduce viral infection and thus increase production, the technique of pruning in tomato can be explored.

The experiment was conducted at Misamis Oriental State College of Agriculture (MOSCAT) in Claveria, Misamis Oriental with the following objectives: (1) evaluate the growth performance of fresh market tomato lines when pruned, (2) determine the yields and its components, and (3) assess the occurrence of Tomato Yellow Leaf Curl Virus (TYLCV) on pruned fresh market tomato lines. This evaluation trial was conducted using potential tomato lines which lessened TYLCV infestation, are high yielding and produced good quality fruits. Additionally, pruning was tested to determine whether it is a worthwhile cultural management practice.

\section{MATERIALS AND METHODS}

\section{Experimental Site}

The study was conducted at the Research Station ( N 08 $\left.36.637^{\prime} E 124^{\sharp} 52.852^{\prime}\right)$ of MOSCAT in Claveria, Misamis Oriental, Philippines from September to December 2014. The site has an elevation of $650 \mathrm{~m}$ above sea level, with soils derived from pyroclastic materials, that are deep, well-drained and representative of most acid uplands in Southeast Asia (Mercado et al 2010).

\section{Experimental Design and Treatments}

The study was laid out in a factorial experiment arranged in a Randomized Complete Block Design (RCBD) with the following treatment combinations: Factor $A$ - pruning $\left(A_{1}=\right.$ Pruned; $A_{2}=$ Unpruned) and Factor $B$ - fresh market tomato lines $\left(B_{1}=A V T O 0101, B 2=A V T O 1173, B_{3}=\right.$ AVTO $1130 \& B_{4}=$ Check Variety). AVTO tomato lines were from the World Vegetable Center which are semi-determinate type in its growth habit. Each treatment combination was replicated three times.

\section{Cultural Management Practices}

The land was plowed and harrowed twice thoroughly using draft animal. A total area of around $315 \mathrm{~m}^{2}$ was divided into 24 plots. Each plot (ie, as one replication) measured $1.5 \mathrm{mx} 6 \mathrm{~m}$ and contained 15 plants per row.

A sterilized media of garden soil, vermi cast, lime and sand having a ratio of $4: 5: 1 / 2: 1$ on a seedling tray was used as the planting medium. Each tomato seedling was raised in an enclosed site, protected with nylon net prior to transplanting. In each plot, the tomato seedlings were transplanted in double rows at a planting distance of $1.5 \mathrm{mx} 0.4 \mathrm{~m}$.

Basal application was done with commercial organic fertilizer having a rate of 
$20 \mathrm{~g}$ plus $10 \mathrm{~g}$ of complete fertilizer (14-14-14). Side dress application was done following the rate of $90-120-60 \mathrm{~kg} \mathrm{~N}, \mathrm{P}_{2} \mathrm{O}_{5}, \mathrm{~K}_{2} \mathrm{O}$ per hectare using complete (14-1414), urea (46-0-0) and muriate of potash (0-0-60) as fertilizer material, respectively. These were also applied as side dressings and soil drenching. Drenching was applied weekly after every harvest. Likewise, weekly spraying of cypermethrin, methomyl and chlorothalonil was done to control insect pests and diseases.

Trellising was setup 30 to 35 days after transplanting. Pruning was done 30 days after transplanting using pruning shears, and involved removal of lateral shoots that developed, maintaining two stems per plant.

Harvesting began at 61 days after transplanting, with four subsequent harvests. Tomatoes were harvested at mature green stage, and then classified as marketable or non-marketable.

\section{Data Collection and Analysis}

Growth parameters such as plant height $(\mathrm{cm})$, stem diameter $(\mathrm{cm})$, and TYLCV Incidence (\%) and severity assessment were gathered following the rating scheme: 1-resistant (very minimal or no symptom), 2-mild symptoms (light foliar yellowing), 3-moderate symptoms (light foliar yellowing, curling, and slight plant stunting) and 4-severe symptoms (very severe plant stunting, leaf size reduction, leaf curling \& yellowing). Yield parameters collected included: percent fruit set (\%), weight per fruit (g), fruit size (cm), number and weight (g) of fruits per plant, and total yield (t ha $\left.{ }^{1}\right)$.

Data obtained were subjected to analysis of variance (ANOVA) using ASSISTAT (version 7.0 beta). The Tukey test was used to determine significant differences among treatments means at $(p<0.05)$ level of significance.

\section{RESULTS AND DISCUSSIONS}

\section{Growth Parameters}

Pruning did not influence the height of tomato at different growth stages but reported an increase on stem diameter (Table 1). Among the tomato lines, AVTO 1130 was the tallest at 45 DAT while AVTO 0101 and 'Check' were the shortest. The different tomato lines differed only in stem diameter at 60 DAT with AVTO 1130 having the thicker stem compared with the rest of the AVTO tomato lines and 'Check', 'Harabas'. Pruning increased stem diameter for the possible reasons of allowing more availability of nutrients, water, (Goda et al 2014) and more light penetration thus increasing photosynthesis efficiency (Preece \& Read 2005). Thornley (1999) reported that diameter growth rate ratio is a function of within-plant allocation ratio and plants can allocate biomass to leaves, stems, and roots (Poorter \& Sack 2012). Pruning likely reduces competition for assimilates, increasing the allocation to the stem and remainder of the plant. Among varieties, AVTO 1130 was the tallest (45 DAT) and got thicker stem (60 DAT). Considering that different tomato cultivars may have different plant architecture and growth habits, the effect of pruning on height and stem diameter varies. 
Performance of fresh market tomato

Table 1. Plant height and stem diameter of pruned and unpruned tomatoes at 30,45 and 60 DAT

\begin{tabular}{lcccccc}
\hline \multirow{2}{*}{ Treatments } & \multicolumn{3}{c}{$\begin{array}{c}\text { Plant Height } \\
(\mathrm{cm})\end{array}$} & \multicolumn{3}{c}{$\begin{array}{c}\text { Stem Diameter } \\
(\mathrm{mm})\end{array}$} \\
\cline { 2 - 6 } & 30 DAT & 45 DAT & 60 DAT & 30 DAT & 45 DAT & 60 DAT \\
\hline $\begin{array}{l}\text { Pruning (A) } \\
\quad \text { Pruned }\end{array}$ & 47.70 & 56.07 & 64.03 & $5.05 \mathrm{a}$ & $8.30 \mathrm{a}$ & $9.11 \mathrm{a}$ \\
$\quad$ Unpruned & 44.23 & 56.53 & 64.48 & $4.50 \mathrm{~b}$ & $6.15 \mathrm{~b}$ & $6.88 \mathrm{~b}$ \\
\hline Tomato Lines (B) & & & & & & \\
$\quad$ AVTO 0101 & 43.70 & $53.86 \mathrm{~b}$ & 62.40 & 4.97 & 6.80 & $7.43 \mathrm{~b}$ \\
AVTO 1173 & 43.83 & $57.43 \mathrm{ab}$ & 66.13 & 4.97 & 7.60 & $8.17 \mathrm{ab}$ \\
AVTO 1130 & 48.27 & $60.43 \mathrm{a}$ & 67.83 & 4.53 & 7.70 & $8.62 \mathrm{a}$ \\
Harabas (Check) & 48.07 & $53.47 \mathrm{~b}$ & 60.67 & 4.63 & 6.80 & $7.77 \mathrm{ab}$ \\
\hline
\end{tabular}

DAT - Days after transplanting

Means in a column having the same letter are not significantly different at $5 \%$ level.

\section{Yield and Yield Components}

Pruned plants produced more fruits as indicated by a higher percentage fruit set of $18.3 \%$ compared to $15.4 \%$ in unpruned plants (Table 2). However, the weight per fruit and fruit size were unaffected by pruning. Other studies have also found increased fruit set in tomato through pruning as it was effective in amplifying fruit setting (Ambroszczyk et al 2008). It could also be possibly related to the source-sink ratio (Chitwood 2013), which can be altered by numerous factors including light levels, plant densities, leaf pruning or genetic background (Natwick 2007).

Table 2. Yield and yield components of pruned and unpruned tomato lines

\begin{tabular}{|c|c|c|c|c|c|c|}
\hline Treatments & $\begin{array}{l}\text { Percent } \\
\text { Fruit Set }\end{array}$ & $\begin{array}{l}\text { Weight Per } \\
\text { Fruit }\end{array}$ & $\begin{array}{l}\text { Fruit } \\
\text { Size }\end{array}$ & \multicolumn{2}{|c|}{ Number of Fruits Per Plant } & \multirow[t]{2}{*}{$\begin{array}{l}\text { Yield } \\
\left(\mathrm{t} \mathrm{ha}^{-1}\right)\end{array}$} \\
\hline Pruning (A) & & & & Marketable & Non-Marketable & \\
\hline Pruned & $18.33 a$ & 32.10 & 4.34 & $16.41 a$ & $14.20 \mathrm{a}$ & $14.49 a$ \\
\hline Unpruned & $15.42 b$ & 32.90 & 4.46 & $12.18 b$ & $11.60 \mathrm{~b}$ & $10.89 \mathrm{~b}$ \\
\hline \multicolumn{7}{|l|}{ Tomato Lines (B) } \\
\hline AVTO 0101 & 14.66 & $31.00 \mathrm{bc}$ & $3.81 b$ & $13.50 \mathrm{~b}$ & $10.43 b$ & $11.21 b$ \\
\hline AVTO 1173 & 17.85 & $35.03 a$ & $5.04 a$ & $13.77 b$ & $14.93 a$ & $13.35 a$ \\
\hline AVTO 1130 & 18.55 & $29.88 \mathrm{c}$ & $5.05 a$ & $15.53 a$ & 13.10ab & $12.95 a$ \\
\hline Harabas (Check) & 16.43 & $34.08 \mathrm{ab}$ & $3.69 b$ & 14.40ab & $13.13 a b$ & $13.25 a$ \\
\hline
\end{tabular}

There was no difference in the percentage fruit set among the lines, but they differed in the weight per fruit and fruit size. AVTO 1173 consistently produced the heaviest and largest fruit. AVTO 1130 fruit size was comparable to AVTO 1173, but its weight was lower than 'Check' and was smaller than AVTO 1173. The size and weight per locule could be a dependable factor on fruit weight (Dillard 2010). Furthermore, higher fruit set through pruning promoted earlier fruit production that constitutes larger fruits (Richardson 2012). Though AVTO 1173 and AVTO 1130 
obtained similar fruit sizes, however the latter had lower weight per fruit. This can be associated with the number of locules in the fruit, in which AVTO 1173 (Figure 1) has more locules than AVTO 1130 (Figure 2) having more compact flesh.

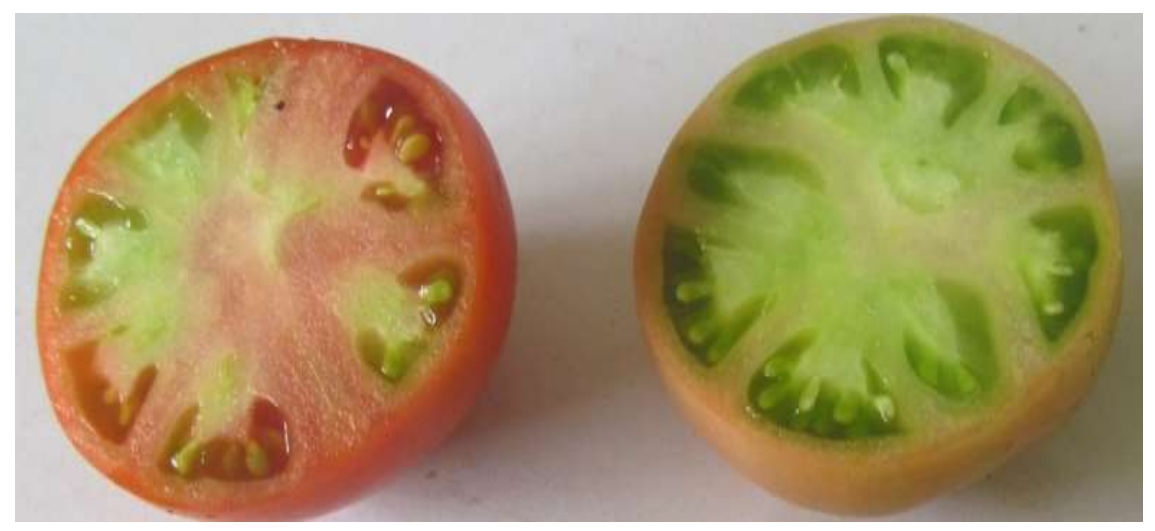

Figure 1. Division of the locule for tomato line AVTO 1173

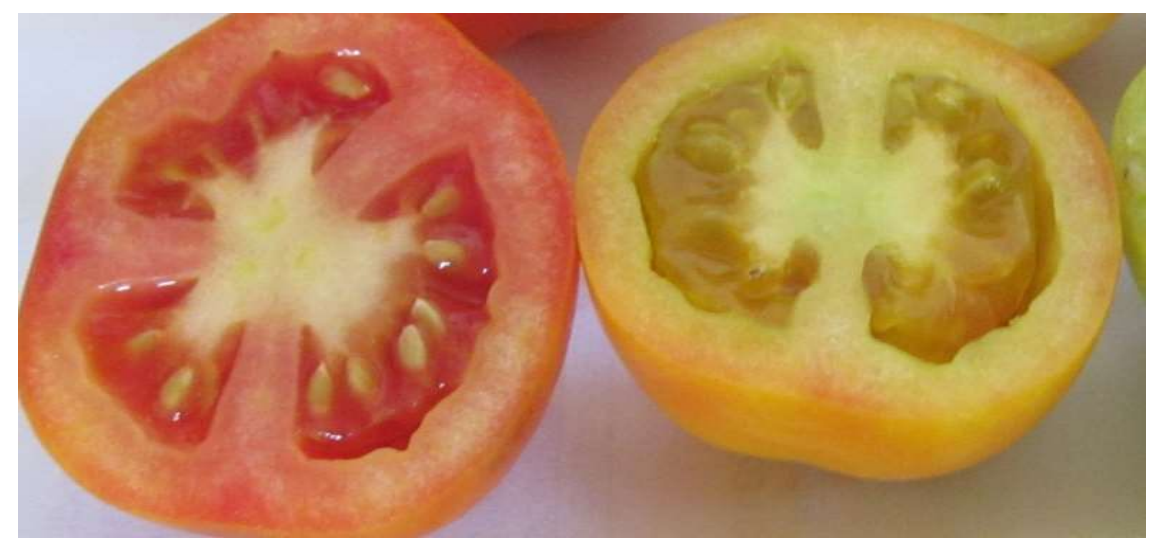

Figure 2. Division of the locule in the tomato line AVTO 1130

Pruned plants had $24 \%$ increased harvest than unpruned (Table 2). Except AVTO 0101, all tomato lines produced a higher yield than 'Check', with the yield ranging from 12.95-13.35t ha-1. One of the major contributors is having higher fruit set percentage on pruned tomatoes resulted into increase in yield. As pruning affected the effectiveness of fruit setting, it ables to set more the flowers into fruits encouraging more space and fewer shades to favourably receive sunlight because lack of sunlight prevents flowering and fruit set (Ambroszoyk et al 2008). Another factor contributed in pruned plants producing more harvest is producing more fruit per plant (Richardson 2012) and produce more foliage left for facilitating photosynthesis on the plant (Gao et al 2010). 
Performance of fresh market tomato

Table 2. Yield and yield components of pruned and unpruned tomato lines

\begin{tabular}{|c|c|c|c|c|c|c|}
\hline Treatments & $\begin{array}{c}\text { Percent } \\
\text { Fruit Set } \\
(\%)\end{array}$ & $\begin{array}{l}\text { Weight Per } \\
\text { Fruit } \\
\text { (grams) }\end{array}$ & $\begin{array}{l}\text { Fruit } \\
\text { Size } \\
(\mathrm{cm})\end{array}$ & \multicolumn{2}{|c|}{ Number of Fruits Per Plant } & $\begin{array}{c}\text { Yield } \\
\left(\mathrm{t} \mathrm{ha}^{-1}\right)\end{array}$ \\
\hline \multicolumn{3}{|l|}{ Pruning (A) } & \multicolumn{4}{|c|}{ Marketable Non-Marketable } \\
\hline Pruned & $18.33 a$ & 32.10 & 4.34 & $16.41 a$ & $14.20 \mathrm{a}$ & $14.49 \mathrm{a}$ \\
\hline Unpruned & $15.42 \mathrm{~b}$ & 32.90 & 4.46 & $12.18 \mathrm{~b}$ & $11.60 \mathrm{~b}$ & $10.89 b$ \\
\hline \multicolumn{7}{|l|}{ Tomato Lines (B) } \\
\hline AVTO 0101 & 14.66 & $31.00 \mathrm{bc}$ & $3.81 \mathrm{~b}$ & $13.50 \mathrm{~b}$ & $10.43 b$ & $11.21 \mathrm{~b}$ \\
\hline AVTO 1173 & 17.85 & $35.03 a$ & $5.04 a$ & $13.77 \mathrm{~b}$ & $14.93 a$ & $13.35 a$ \\
\hline AVTO 1130 & 18.55 & $29.88 \mathrm{c}$ & $5.05 a$ & $15.53 a$ & 13.10ab & $12.95 a$ \\
\hline Harabas (Check) & 16.43 & $34.08 \mathrm{ab}$ & $3.69 \mathrm{~b}$ & 14.40ab & 13.13ab & $13.25 a$ \\
\hline
\end{tabular}

Means in a column having the same letter are not significantly different at $5 \%$ level

\section{Incidence of Tomato Yellow Leaf Curl Virus (TYLCV)}

Unpruned tomato lines showed a higher TYLCV incidence than pruned at 30 and 45 DAT (Table 3). According to Santos and Vallad (2013), pruning increases air and moisture flow through reducing of leaves thus reduces humidity and it would appear having less crowded and shaded leaves, which remain warmer, possibly the reason why unpruned plants tend to have more severe TYLCV infection compared to pruned plants. Pruning also improves plant health and lessen pests and diseases incidence. The leaves of pruned plants dry faster reducing attractive sites for disease establishment (Ferrandino 2010). Moreover, Gao et al (2010) recommended proper spacing and plant support for good plant health.

Table 3. Incidence and severity of TYLCV among fresh market tomato lines as influenced by pruning

\begin{tabular}{|c|c|c|c|c|c|c|}
\hline \multirow{2}{*}{ Treatments } & \multicolumn{3}{|c|}{ TYLCV Incidence (\%) } & \multicolumn{3}{|c|}{ TYLCV Severity } \\
\hline & 30 DAT & 45 DAT & 60 DAT & 30 DAT & $45 \mathrm{DAT}$ & 60 DAT \\
\hline \multicolumn{7}{|l|}{ Pruning(A) } \\
\hline Pruned & $36.66 \mathrm{~b}$ & $56.66 \mathrm{~b}$ & 66.10 & $1.43 b$ & $2.03 b$ & 2.75 \\
\hline Unpruned & $59.44 a$ & $66.67 a$ & 74.44 & $1.82 \mathrm{a}$ & $2.37 a$ & 2.70 \\
\hline \multicolumn{7}{|l|}{ Tomato Lines (B) } \\
\hline AVT0 0101 & 46.67 & 57.83 & 70.00 & 1.63 & $2.30 a b$ & 2.63 \\
\hline AVTO 1173 & 48.89 & 66.66 & 72.22 & 1.50 & $1.93 b$ & 2.70 \\
\hline AVTO 1130 & 48.88 & 66.66 & 69.99 & 1.60 & $2.37 a$ & 2.87 \\
\hline Harabas (Check) & 47.77 & 55.55 & 68.88 & 1.77 & $2.20 \mathrm{ab}$ & 2.70 \\
\hline
\end{tabular}


There was a significant interaction between tomato lines and pruning, in which all AVRDC lines responded positively to pruning, reducing the incidence of TYLCV compared to the check variety at 30 DAT. AVTO 0101 consistently exhibited significantly lower TYLCV incidence at 45 DAT. A key result in the severity of TYLCV was AVTO 1173 exhibited the lowest severity infection as it contains Ty-1, Ty-2, and Ty-3 genes along with AVTO 0101 (AVRDC 2010). In contrast, AVTO 1130 showed the highest TYLCV severity which contains Ty-2 and Ty-3 genes only, which could be accounted for the high severity of infection in the latter.

\section{CONCLUSIONS}

Study has shown that pruning increased stem diameter and fruit set, produced healthier plants by reducing TYLCV and increased the yield of tomato. Among the AVRDC lines, AVTO 1173 produced the heaviest and largest fruit. AVTO 1173 was better than 'Harabas', the check variety. Eventough with noted increase in yield and its components still it could not compensate with the cost required for labor. However, pruned tomatoes were highly tolerant to TYLCV.

The results highlight the potential benefits for farmers to adopt tomato pruning partincularly useful in mitigating TYLCV incidence and the use of AVTO 1173 as a substitute planting material. Additional trials should be conducted in different locations to further verify the adaptability and performance of AVTO 1173.

\section{REFERENCES}

Asian Vegetable Research and Development Center (AVRDC). 2010. Improved vegetable lines retrieved on January 2015 from http://avrdc.org/seed/ improved-lines/

Chen JT and Lal G. 1999. Pruning and staking tomatoes. AVRDC International Cooperators Guide. AVRDC pub 9-490

Chitwood DH, Kumar R, Headland LR, Ranjan A, Covington MF, Ichihashi Y \& Sinha NR. 2013. A quantitative genetic basis for leaf morphology in a set of precisely defined tomato introgression lines. The Plant Cell 25(7):2465-2481

Dillard H. 2010. Diagnosing Tomato Problems. College University and College of Agriculture and Life Sciences

Ferrandino FJ. 2010. Pruning, Training, and Supporting Tomatoes. The Connecticut Agricultural Experiment Station

Gao G, Bergefurd B \& Precheur B. 2010. Growing Tomatoes in the Home Garden. Agriculture and Natural Resources

Goda Y, El-Rehim A, Mohamed AA, Helaly AA \& El-Zeiny OAH. 2014. Effect of shoot Pruning on Growth, Yield and Fruit Quality of Husk Tomato (Physalis pubescens L.). Journal of American Science 10(1):5-10

Kanyomeka L and Shivute B. 2005. Influence of pruning on tomato production under controlled environments. Agricultura Tropicaet Subtropica 32(2):79-81

Mercado JR A, Tulin A, Dorahy C, Gilkes R \& Prakongkep N. 2010, August. Soil management and crop nutrition for tomato in acid soil of Claveria, Philippines. In Proceedings of the 19th World Congress of Soil Science: Soil solutions for a changing world (pp270-273)

Muhammad A and Singh A. 2007. Yield of tomato as influenced by training and pruning in the Sudan savanna of Nigeria. Journal of Plant Science 2(3):310-317 
Performance of fresh market tomato

Natwick E. 2007. Controlling tomato yellow leaf curl virus. UCCE Entomology Farm Advisor Imperial County, California Western Farm Press

Poorter H and Sack L. 2012. Pitfalls and possibilities in the analysis of biomass allocation patterns in plants. Frontiers in plant science 3:259

Richardson K. 2012. The Effects of Pruning Versus Non-Pruning on Quality and Yield of Staked Fresh-Market Tomatoes. Gladstone Road Agricultural Centre. Department of Agriculture.

Santos B and Vallad G. 2013. Cultural Practices for Vegetable and Small Fruit Crops: Does Shoot Pruning Improve Tomato Yield and Reduce Bacterial Spot Infestation. Publication \# HS1 180

Thornley JH. 1999. Modelling stem height and diameter growth in plants. Annals of Botany 84(2):195-205 